\title{
15. \\ ZAGREBAČKI STUDENTI \\ U PRVOM DESETLJEĆU \\ NAKON DRUGOGA SVJETSKOG RATA
}

\section{Magdalena Najbar-Agičić}

UDK: 37.091.212(497.5 Zagreb)“194/195“

Izvorni znanstveni članak

Sažetak: U članku se na temelju arhivske građe Sveučilišnog komiteta KPH/SKH Sveučilišta u Zagrebu analizira politička situacija među studentima na Sveučilištu te različiti aspekti studentskog života, koji su opisani u partijskim referatima i izvještajima. Tako se dopunjuje slika vezana uz povijest Zagrebačkog sveučilišta, ali i općenito politiku komunističkih vlasti prema Sveučilištu, što je pogotovo značajno s obzirom na to da je Zagreb u analiziranom razdoblju bio jedini hrvatski sveučilišni centar. U vezi s političkom situacijom prikazuje se slika političkih protivnika komunista na temelju korištenih izvora, kao i kretanje broja članova KPH/SKH na Sveučilištu. Ukazuje se na oblike političke propagande te akcije koje je Partija provodila s ciljem uspostave snažnije kontrole i većeg utjecaja na studentsku populaciju (primjerice, radne akcije), a poglavito na rad u sklopu omladinske organizacije. Iznose se podaci iz arhivske građe $\mathrm{u}$ vezi sa socijalnim sastavom studenata te različitim aspektima svakodnevnog života studenata Sveučilišta u Zagrebu u prvom desetljeću nakon Drugoga svjetskog rata. Donosi se slika kulturnih i sportskih aktivnosti studenata, ali i saznanja o materijalnim uvjetima njihova života.

Ključne riječi: Sveučilišste u Zagrebu, KPH/SKH, studenti, Sveučilišni komitet

边

azdoblje nakon Drugoga svjetskog rata obilježavaju ubrzane promjene na svim područjima života, a u Zagrebu, kao najvećem hrvatskom gradu, manifestiraju se posebno snažno. U to je vrijeme Zagreb bio jedini hrvatski sveučilišni centar pa s pravom privlači pozornost svih istraživača koji se bave promjenama u znanosti i sveučilišnom životu u svim njegovim aspektima, od politike vlasti do svakodnevnog života studenata. Studentska populacija u godinama nakon 1945. doživjela je eksponencijalan brojčani porast, koji nije moguće uspoređivati ni s jednim prethodnim povijesnim razdobljem. Velik porast broja studenata te političke promjene u kojima se to događalo utjecali su na društvenu strukturu studenata, način odvijanja nastave, odnos profesora i studenata te mnogo toga drugoga, sve do načina života i svakodnevnih problema s kojima su se studenti morali nositi. ${ }^{1}$

$1 \quad$ Magdalena Najbar-AgičIć, Kultura znanosti ideologija. Prilozi istraživanju politike komunističkih vlasti u Hrvatskoj od 1945. do 1960. na polju kulture i znanosti, Zagreb 2013. 
Nove su komunističke vlasti nastojale uspostaviti maksimalnu kontrolu nad različitim aspektima studentskog života uz pomoć partijske i omladinske organizacije te su one ostavile iza sebe bogatu arhivsku građu. Omladinskom organizacijom Komunistička partija nastojala je oblikovati mlade naraštaje, pogotovo one buduće inteligencije, prijeko potrebne zemlji u planiranom razvoju. Iako snažno ideologizirane, te su organizacije pratile i nastojale mijenjati uvjete studentskog života, suzbijati negativne pojave te podizati razinu studentskog standarda. U ovom članku prezentirat će se samo neka osnovna kretanja na tome polju tijekom prvih deset poslijeratnih godina na temelju materijala Sveučilišnog komiteta i izvještaja sa sveučilišnih partijskih konferencija. ${ }^{2}$

\section{Politička situacija na Sveučilištiu}

\section{I. POLITIČKi PROTIVNICI}

Iako se praktički u cijelom socijalističkom razdoblju naglašavao utjecaj komunista među mladima, a problemi s uspostavom monopola komunistima predvođenih omladinskih organizacija nisu se uopće javno isticali, u stvarnosti su se u početnom razdoblju poslije 1945. komunisti suočavali s prisutnošću među studentima onih koje su smatrali svojim protivnicima te s pokušajima djelovanja organizacija drugih političkih orijentacija ili barem s onima koji im se nisu bili skloni podrediti. U kronološki najstarijem dokumentu (iz 1946.) situacija je opisana ovako:

Reakcionarne grupice su se na fakultetima pomalo sredile i nastoje, da se prošire. One nisu povezane, služe se pojedinačnim istupima, ali promatrajući ih zajedno vidi se da se njihov rad pored gore navedenih momenata očituje se na dva načina: a) što $s$ jedne strane bojkotuju rad naših vanpartijskih organizacija tvrdeći da se ne treba kompromitirati u režimskim organizacijama, jer će doći nešto treće, okupljaju se i agituju među novim još nezainteresovanim stud. i b) s druge strane učestvuju u radu kluba i naših organizacija, prisustvuju manifestacijama i sastancima, aktivišu se u radu, nastoje se popularisati i vezati uz sebe grupice drugih studenata. ${ }^{3}$

Nešto kasnije u partijskim se referatima ovako opisuje političku strukturu studenata: „Na sveučilištu se naročito u prvo vrijeme poslije rata iz redova otvorenih neprijatelja još u doba stare Jugoslavije ili iz razdoblja oružane borbe našla grupa reakcionera koji su is-

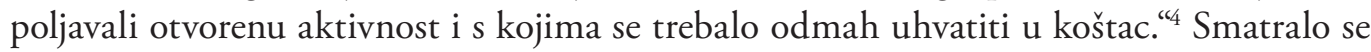
da je i dalje među studentima prisutan utjecaj prijeratnih političkih odnosa na Sveučilištu, naročito „frankovaca“, te „specijalnih prilika u Hrvatskoj“ i „izdajničke politike vodstva

2 Spomenutu arhivsku građu pripremam za objavljivanje u zasebnoj ediciji.

3 Državni arhiv u Zagrebu (dalje: HR-DAZG-684), fond Gradski komitet Saveza komunista Hrvatske, kut. 27, Sveučilišni komitet, fasc. 2/6 Referati Sveučilišnog komiteta (dalje: HR-DAZG-684, Referati Sveučilišnog komiteta), Politička situacija na Zgb. sveučilištu, (1946.?).

4 HR-DAZG-684, Referati Sveučilišnog komiteta, O međunarodnoj političkoj situaciji, našoj unutarnjoj politici i zadacima Partije na sveučilištu, 1949. 
HSS na čelu sa Mačekom“. Radilo se sve što je bilo moguće kako bi se povećao udio komunista među studentima jer su se oni smatrali „nosiocima tog novog života“. Ipak, njih je ustvari bilo relativno malo, a pored komunista, na Sveučilištu je bilo (kako je procjenjivao KP) oko 3.000 onih koji su se doživljavali neprijateljima: „domobrani, pripadnici raznih drugih neprijateljskih formacija i ustaške radne službe “. ${ }^{6}$ Smatralo se da je većina studenata zapravo stajala „po strani“, tijekom rata bavila se naprosto studiranjem, ali i da je ta većina bila „više pod uticajem neprijatelja nego pod uticajem našeg pokreta“?

Zbog svega toga je u prvom poslijeratnom razdoblju djelovanje partijske organizacije na Sveučilištu karakterizirala borba protiv, kako se tvrdilo: „ustaško-mačekovskih i klero-fašističkih elemenata“ ${ }^{8}$ Kasnije se govorilo: „To je za našu organizaciju bilo centralno pitanje i radi toga smo bili zapustili sve ostale zadatke.“99 Partija nije bila zadovoljna postignutim rezultatima. Nakon sedam godina, 1952., partijske vlasti uočavaju zabrinjavajuće djelovanje „proustaških i klerikalnih“ neprijateljskih elemenata. Negativne su se pojave prvenstveno primjećivale na sportskim utakmicama, a išle su u pravcu „podrivanja najdragocjenijeg ploda naše narodne revolucije - bratstva i jedinstva naših naroda“. Pored toga, Partiju su već tada zabrinjavale rasprave vezane uz pitanja jezika te „tendenciozno povlačenje paralela BeogradZagreb" i tome slično. ${ }^{10}$ Ove zabilješke, koje potječu iz razdoblja relativne liberalizacije sustava, ne trebaju iznenaditi. Upravo je „popuštanje“ omogućilo izbijanje na površinu onih tendencija koje su u vrijeme razdoblja pojačanog pritiska krajem 1940-ih bile potisnute: ljudi su s nešto manje straha izražavali svoje stavove koji su često bili suprotni službenoj liniji.

\section{2. BROJ KOMUNISTA}

Koliko je god brojka od tri tisuće aktivnih političkih protivnika zasigurno pretjerana, nema sumnje da je najviše bilo onih pasivnih, koji su iščekivali razvitak situacije, koji su se nastojali naprosto prilagoditi novonastalim okolnostima. Na njih se prvenstveno orijentirala partijska propaganda, nastojalo ih se u početku prvenstveno uključiti u masovne organizacije, koje su od početka bile pod kontrolom Komunističke partije, ali i povećati brojčano stanje članova Partije na Sveučilištu.

Počeci su bili malo obećavajući za komuniste. Nakon kraja rata na Sveučilištu je bilo svega tridesetak komunista koji su svoje prve ćelije osnovali na Medicinskom i Farmaceutskom fakultetu, a do prosinca 1945., dakle do obnove rada Sveučilišta, ćelije su osnovane i na drugim fakultetima zahvaljujući upisu stanovitog broja studenata-komunista sudionika NOP-a. ${ }^{11}$ Početkom 1946. godine formiran je i posebni Sveučilišni komitet KPH (dotad je

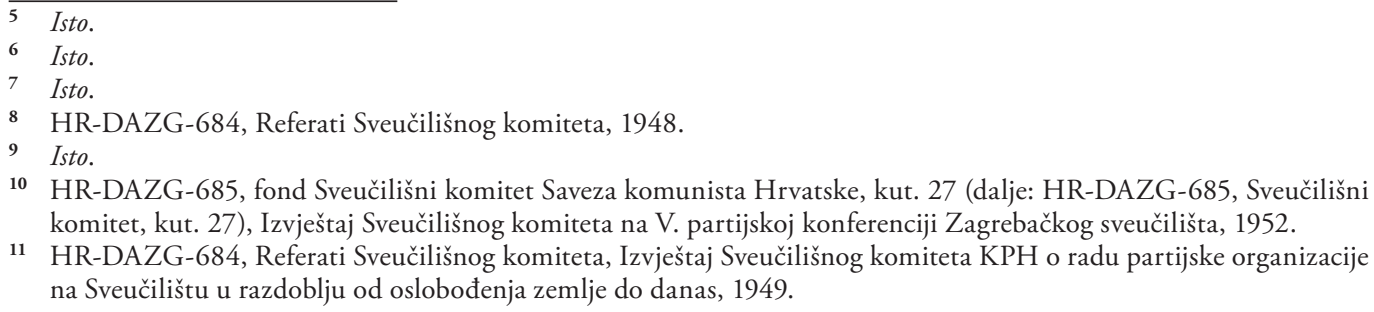


djelovao Sveučilišni biro). ${ }^{12} \mathrm{Na}$ raspolaganju je jako malo izvještaja i općenito dokumenata iz razdoblja prije 1948. godine, stoga nije moguće u potpunosti rekonstruirati kretanje broja članova Partije među studentima. Čini se kako su i same partijske strukture imale slab uvid u kretanje tog broja. U Izvještaju s II. konferencije (1949.), gdje bi se trebale naći detaljne brojke kretanja partijskog članstva, mjesta za brojke ostala su nepopunjena. ${ }^{13}$ Prvi podatak koji imamo potječe iz dokumenta koji bi se mogao datirati u 1946. godinu. U njemu stoji da je KPH na Sveučilištu tada imao 176 članova i da je tijekom te godine primljeno njih 6 . Konstatira se također da bi trebalo više poraditi na tome. ${ }^{14} \mathrm{U}$ nekim se dokumentima broj članova Partije i SKOJ-a iskazuje zajedno, a u nekima odvojeno. Primjerice, u jednom se dokumentu (koji možemo datirati u kraj 1946. - godina na samom dokumentu dopisana je rukom - 1949. - ali je vjerojatno pogrešna) spominje 900 članova Partije i SKOJ-a, pri čemu se u istom dokumentu spominje 500 članova SKOJ-a, što navodi na zaključak da je članova Partije bilo oko četiri stotine. ${ }^{15}$

Sljedeći podaci potječu iz 1947. godine (godina na dokumentu dopisana rukom jest 1948., ali se vjerojatno radi o ranijim podacima). Saznajemo da je u siječnju 1947. organizacija bila najbrojnija jer je imala 1.080 članova, a „po otcjepljenju vojnih pitomaca“ (što se dogodilo u ožujku 1947.), taj se broj nešto smanjio. Krajem 1947. Partija je imala 797 članova KPJ te 70 kandidata i 1.023 člana SKOJ-a. Pored toga, računalo se na još oko 300 članova Partije, koji su bili „nepovezani, budući nisu stigli njihovi dokumenti“ ${ }^{16}$

Na početku 1948. godine partijska organizacija brojila je 990 članova i 82 kandidata, a postojala je i organizacija SKOJ-a s 1.369 članova. Tijekom te godine došlo je do stanovitog povećanja članstva, tako da je na kraju 1948. godine partijska organizacija brojila 2.151 člana i 80 kandidata za člana. Kako se ističe, tijekom 1948. godine u Partiju su na Sveučilištu primljena 682 nova člana. Istovremeno je iz Partije isključeno 148 članova (od toga 138 zbog „kolebanja“ ili „antipartijskog rada na liniji rezolucije Informbiroa“), a kažnjen $41 .{ }^{17}$ Nije jasno koje su od navedenih brojki vjerodostojne jer se njihov zbroj ne poklapa.

Godina 1948. bila je vrlo turbulentna. Na djelu je bilo „zaoštravanje stava prema neprijateljskim elementima i odlučna borba s njima“ pa je čišćenje u redovima sveučilištaraca bilo vezano ne samo uz sukob s IB-om. U referatu iz 1949. navodi se da je „sa Univerziteta istjerano ukupno 257 studenata, od toga na liniji Informbiroa 148 a ostalih 109, bez posljednje grupe u kojoj je predloženo za isključenje 205 studenata“ ${ }^{18}$ Godine 1949. ukupno je na Sveučilištu bilo 37 ćelija sa 130 odjeljenja. Brojčano stanje članova Komunističke partije iznosilo je 1.952, kandidata 73 i članova SKOJ-a $721 .^{19}$

\footnotetext{
12 Isto.

13 Isto.

14 HR-DAZG-684, Referati Sveučilišnog komiteta, Drugovi i drugarice komunisti..., (1948.?).

15 HR-DAZG-684, Referati Sveučilišnog komiteta, Politička situacija na Zgb. sveučilištu, (1946.?).

16 HR-DAZG-684, Referati Sveučilišnog komiteta, 1948. (Rukom)

17 HR-DAZG-684, Referati Sveučilišnog komiteta, Izvještaj o situaciji i radu partijske organizacije na Sveučilištu za 1948. godinu.

18 HR-DAZG-684, Referati Sveučilišnog komiteta, Politička situacija na sveučilištu, 1949.

19 HR-DAZG-684, Gradski komitet SKH, kut. 27, fasc. II/7: Komitet Sveučilišta (Pogrešno datiran na 1952. godinu, a potječe najvjerojatnije iz 1949.).
} 
Broj profesora koji su bili članovi Partije vrlo se malo mijenjao. Kada su u pitanju studenti, situacija je izgledala mnogo povoljnije za Partiju. Najznačajniji brojčani porast dogodio se 1947. godine. Partijska organizacija studenata godine 1951. brojila je 2.716 članova od 12.624 upisana studenta, što je činilo $21,5 \%$ studentske populacije. ${ }^{20}$ Tada je bila i najviša u promatranom razdoblju. Godine 1952. broj članova Partije na Sveučilištu iznosio je 2.331, od toga nastavnika 257, a studenata $2.074 .{ }^{21}$ Ipak, kasnije dolazi do stagnacije, odnosno čak do stanovitog opadanja. Krajem 1953. na Sveučilištu je bilo 2.160 članova SKJ (i to nastavnika 231, studenata 1.929), ${ }^{22}$ a godinu kasnije 2.091 član (od toga nastavnika 233 i studenata 1.858), što je značilo da je svaki sedmi student, odnosno 14\% od ukupnog broja, bio član Partije. ${ }^{23}$

Vodstvo Sveučilišnog komiteta moralo je priznati da su te godine „karakteristične po opadanju broja komunista“. Dodatno, na mnogim je fakultetima situacija bila takva da su većinu članova činili apsolventi (primjerice, na Veterinarskom fakultetu čak više od 50\%), a na prvim godinama studija bio je vrlo malen broj komunista. ${ }^{24}$ Do kraja promatranog razdoblja situacija je ostala slična. Potkraj 1954. godine, u vrijeme kada je održana sljedeća sveučilišna konferencija, u organizaciji Saveza komunista na Sveučilištu bio je 2.041 član, a godinu dana kasnije bilo je 1.913 članova, što je značilo smanjenje broja članova za nešto više od dvije stotine, oko $5 \% .{ }^{25}$ Sve se to događalo usprkos tomu što je ustanovljeno da su na cijelom Sveučilištu bila samo trojica „sljedbenika Đilasa“. Smatralo se ipak da je „u danima Đilasovskih 'pisanija' pritisak raznih malograđanskih i neprijateljskih elemenata bio vrlo jak. To je naročito djelovalo na neke kolebljivce u SK koji su izgubili orijentaciju, a jedan dio i nasjeo nekim njegovim teorijama". ${ }^{26}$ Tako je bilo bez obzira na to što je sveučilišna karijera predviđena upravo za članove KP-a, a što je bilo dijelom politike usmjerene prema povećanju broja komunista među nastavnicima. ${ }^{27}$

\section{3. NARODNA OMLADINA ${ }^{28}$}

Od 1947. godine dolazi do pomasovljenja partijskog članstva na Sveučilištu, no još se uvijek radi o manjini koja se kreće između 12 i 14\% (izuzetak čini 1951., kada raste do

20 Hrvatski državni arhiv (dalje: HR-HDA-1220), fond Centralni komitet Saveza komunista Hrvatske (dalje: CK SKH), serija Agitprop, kut. 13, Izvještaj ekipe CK KPH o stanju i radu partijskih organizacija na Zagrebačkom univerzitetu 12. I. 1952.

21 HR-DAZG-685, Sveučilišni komitet, kut. 27, Izvještaj Sveučilišnog komiteta na V. partijskoj konferenciji Zagrebačkog sveučilišta, 1952.

22 HR-DAZG-685, Sveučilišni komitet, kut. 27, Zapisnik sa VII. konferencije SK studenata i nastavnika Sveučilišta, 1953.

23 HR-DAZG-685, Sveučilišni komitet, kut. 27, Referat na Izvanrednoj konferenciji Sveučilišnog komiteta SK u 1954. godini.

24 HR-DAZG-685, Sveučilišni komitet, kut. 27, Zapisnik sa VII. konferencije SK studenata i nastavnika Sveučilišta, 1953. (dio prekrižen u rukopisu)

25 HR-DAZG-685, Sveučilišni komitet, kut. 27, Izvještaj Sveučilišnog komiteta, 1955.

26 HR-DAZG-685, Sveučilišni komitet, kut. 27, Referat na Izvanrednoj konferenciji Sveučilišnog komiteta SK u 1954. godini.

27 HR-DAZG-684, Referati Sveučilišnog komiteta, Politička situacija na sveučilištu, 1949.

28 O Narodnoj omladini, na temelju građe koja se čuva u Hrvatskom državnom arhivu, pisala je: Tatjana ŠArIć, $U v r-$ tlogu komunizma. Mladi Hrvatske 1945.-1954., Zagreb 2017. 
20\%). Stoga je Partija na šire studentske mase nastojala utjecati uz pomoć masovne omladinske organizacije, Narodne omladine.

Partija je vrlo brzo prožela studentsku zajednicu njezinim masovnim uključivanjem u Narodnu studentsku omladinu. Još je krajem 1946. NO (i sve ostale izvanpartijske organizacije pod kontrolom KP-a) uključivao samo oko $40 \%$ ukupnog broja studenata. ${ }^{29} \mathrm{U}$ narednom se razdoblju situacija s gledišta Partije značajno poboljšala. Godine 1948. 95\% studenata bili su članovi NSO-a. ${ }^{30}$ Pred kraj iste godine organizacija SKOJ-a spojena je s organizacijom Narodne omladine. ${ }^{31}$ Do 1948. godine, dakle, uspjelo se gotovo u potpunosti uključiti studente u masovnu omladinsku organizaciju. U brojkama, na kraju 1948. NO je imao 11.459 članova od 11.667 redovitih studenata (ne računavši vojne studente i strane državljane). ${ }^{32}$

Pritom je organizacija Narodne omladine bila pod izravnom kontrolom Partije. U Sveučilišnom komitetu Narodne omladine od 24 člana 14 je bilo članova Sveučilišnog komiteta KPJ, dok se „biro Komiteta N. O. poklapao gotovo sasvim sa biroom Komiteta Partije (osim jednog člana)“. ${ }^{33}$ Jednako je bilo i na razini fakulteta jer su se rukovodstva fakultetskih komiteta NO-a uglavnom poklapala s fakultetskim komitetima Partije. Za partijske strukture to je stanje bilo neupitno poželjno, odnosno doživljavalo se kao stanje kojim se valja ponositi pa ne začuđuje toliko otvoreno isticanje da „na taj način Partija je ostvarila apsolutno rukovodstvo sa organizacijama N. O.“. ${ }^{34}$

Smisao učinkovitosti djelovanja Partije preko Narodne omladine bila je masovnost te organizacije. U jednom drugom dokumentu iz 1949. kaže se: „U organizaciji Narodne omladine imamo sada 11.200 članova il $96 \%$ od ukupnog broja redovitih studenata (12.472).“ ${ }^{35}$ I kasnije se ističe da je visok udio studenata bio obuhvaćen članstvom u organizaciji Narodne omladine - bilo je uključeno 96\% svih studenata (kako se navodi u jednom izvještaju Agitpropa: $85-90 \%$ studenata redovito je prisustvovalo sastancima grupa i aktiva Narodne omladine), ${ }^{36}$ a to se društvo nalazilo u nadležnosti posebnog odjela Agitpropa pri Sveučilišnom komitetu KPH. ${ }^{37}$ Ipak, preispitujući situaciju, Partija je morala konstatirati da „mnogi od ovih studenata, zapravo velik broj su članovi NSOe samo na papiru“. Kao razlog isticalo se nepovjerljiv stav komunista prema „vanpartijcima“. Samokritički se (u duhu onoga vremena) razlog tražilo u slabostima vlastite organizacije koje je trebalo uklanjati pa je u referatu pisalo da „naša organizacija ima grub, sektaški stav prema velikom broju dobrih studenata vanpartijaca“. Štoviše: „Stvari se postavljaju direktivno.“38

\footnotetext{
29 HR-DAZG-684, Referati Sveučilišnog komiteta, Politička situacija na Zgb. sveučilištu, (1946.?).

30 HR-DAZG-684, Referati Sveučilišnog komiteta, 1948. (Rukom)

31 HR-DAZG-684, Referati Sveučilišnog komiteta, Izvještaj o situaciji i radu partijske organizacije na Sveučilištu za 1948. godinu.

32 Isto.

33 Isto.

34 Isto.

35 HR-DAZG-684, Referati Sveučilišnog komiteta, Politička situacija na sveučilištu, 1949.

36 Branislava Vojnović (prir.), Zapisnici Politbiroa Centralnog komiteta Komunističke partije Hrvatske 1945. - 1952., sv. II.: 1949. - 1952., Zagreb 2006., 156.

37 Stjepan Matкović, „Ocjene Uprave za agitaciju i propagandu KP Hrvatske o povjesničarima na Sveučilištu u Zagrebu do početka 1950-ih“, u: Kultura sjećanja: 1945. Povijesni lomovi i svladavanje prošlosti (ur. Sulejman Bosto i Tihomir Cipek), Zagreb 2009., 228.

38 HR-DAZG-684, Referati Sveučilišnog komiteta, 1948. (Rukom)
} 


\section{4. INDOKTRINACIJA}

Radilo se, dakle, o tome da je NSO imao među studentima sličnu transmisijsku ulogu kakvu su među radnicima imali sindikati. Jedan od osnovnih ciljeva njihova djelovanja bila je indoktrinacija. U brojnim dokumentima sačuvanima u arhivskoj građi naširoko se opisuju potrebe, uspjesi i neuspjesi „preodgoja“, pri čemu je to čudna mješavina političke bezobzirnosti i idealizma. $S$ ponosom se isticalo:

Na primjer mi smo u nekoliko navrata (proslava 1. maja proslava početka frontovskih radova u Zagrebu, prenos kosti Đure Đakovića) izvodili na mitinge i manifestacije preko 8.000 studenata, što nikada ranije nije bio slučaj. Na dobrovoljnim radovima koji su bili organizovani kroz čitavu školsku godinu uzelo je učešća oko $90 \%$ članova Narodne omladine ili $86 \%$ od svih upisanih studenata (redovitih). Od toga $26 \%$ dalo je kroz to vrijeme preko 60 radnih sati, a ostali prosječno po 25-30 radnih sati. U političko ideološkim kursevima bilo je obuhvaćeno uračunavši i članova KP blizu 12.000 studenata, što znači gotovo svi redoviti studenti. Učešće u radu organizacije se je također znatno poboljšalo. 85-90\% studenata redovito je prisustvovalo sastancima grupa i aktiva Narodne omladine. ${ }^{39}$

Bili su različiti oblici rada - tražio se onaj koji bi među studentskom populacijom polučio što bolji rezultat. „Nov način rada u debatnim kružocima, pokazao se vrlo dobrim.“40 Također, organizirane su tzv. „debatne večeri“, ali se smatralo da su one nedovoljno korišten oblik rada jer, $s$ jedne strane, nisu bile previše brojne, a s druge, „i ondje gdje su održane imale su gotovo isključivo stručni karakter", 41 čime Partija nije bila zadovoljna. Indoktrinacija se dijelom provodila u okviru redovite nastave na Sveučilištu, odnosno nastave iz „Marksizma-Lenjinizma“ koji je postao obvezni predmet na gotovo svim fakultetima (osim na Bogoslovnom, Konzervatoriju, Akademiji likovnih umjetnosti i Pedagoškoj školi). ${ }_{4}^{42}$ I tu je Partija imala razlog za zabrinutost jer je „ogromna većina studenata odložila ispit iz ovog predmeta za drugi ispitni rok t. j. za jesen." Konkretno je naveden primjer Poljoprivrednošumarskog fakulteta, na kojem je od 1.600 studenata polaganje tog ispita u prvom ispitnom roku prijavilo samo njih tridesetak (oko $2 \%$ ), a slično stanje bilo je i na drugim fakultetima. ${ }^{43}$

\section{5. RADNE AKCIJE}

I radne se akcije prvenstveno pojavljuju u kontekstu indoktrinacije (jačanja utjecaja na omladinu), a ne u kontekstu pothvatâ koji bi imali gospodarsku važnost. U promatranom razdoblju radilo se prvenstveno o dvjema najpoznatijim radnim akcijama organiziranima za mladež u prvim godinama nakon rata: izgradnji željezničke pruge Šamac - Sarajevo i Brčko - Banovićí. ${ }^{44}$ Te su akcije igrale značajnu ulogu i kao način uključivanja studentske

39 HR-DAZG-684, Referati Sveučilišnog komiteta, Politička situacija na sveučilištu, 1949.

40 HR-DAZG-684, Referati Sveučilišnog komiteta, O radu kroz prošli semestar i zadacima u ljetnom semestru, (1947/1948).

41 Isto.

42 HR-DAZG-684, Referati Sveučilišnog komiteta, Politička situacija na sveučilištu, 1949.

43 Isto.

44 O radnim akcijama, uglavnom u okviru etnološko-antropoloških istraživanja, v. Andrea MatošEvić, „Posrednici u stvaranju socijalističkih ljudi na omladinskim radnim akcijama: utopija, dijalektika i vrijeme“, u: Stvaranje socijalističkog čovjeka. Hrvatsko drustvo i ideologija jugoslavenskog socijalizma (ur. Igor Duda), Zagreb - Pula 2017., 75-96; Reana SenjKović, Svaki dan pobjeda. Kultura omladinskih radnih akcija, Zagreb 2016. 
omladine u Petogodišnji plan. U tom se smislu isticalo da je na gradnji pruge Šamac - Sarajevo sudjelovalo 600 zagrebačkih studenata. ${ }^{45}$

Formalno gledano, odlazak na radne akcije trebao je u potpunosti biti dragovoljan, no postavljao se od početka kao pitanje časti „omladinaca“:

Pitanje odlaska na radne akcije treba postaviti na dobrovoljnoj bazi. Kod toga se ne smije ispoljavati prisila. Stvar je naše organizacije da kroz svestranu agitaciju razvije kod svih članova osjećaj da otići na izgradnju ovih velikih objekata pretstavlja stvar časti svakog člana NSO-e koji je sposoban da učestvuje u takvim radovima. Naša organizacija mora svoje članove upoznati sa svim poteškoćama na koje se nailazi. Ako se jedan student poslije svega toga prijavi u jednu brigadu, onda je on time dao obavezu, dao je časnu riječ da će otići u brigadu. Ako pak kasnije odustane bez ikakvog opravdanog razloga onda je to dokaz krajnjeg nepoštenja i lošeg karaktera dotičnog čovjeka. U takve ljude, a osobito ako su oni to po drugi put učinili naša organizacija ne može imati nikakvog povjerenja. ${ }^{46}$

Službeno se isticao velik zanos kojim je omladina pristupala sudjelovanju u radnim akcijama: „Naše partijsko i SKOJevsko članstvo obuzelo je radno oduševljenje.“ ${ }^{“ 77}$ Praksa je ipak bila ponešto drugačija, a bilo je jasno da se bez velike propagandne akcije, pa i bez nametanja radnih akcija kao svojevrsne obveze, teško moglo postići željenu „mobilizaciju“. $\mathrm{Ne}$ bez stanovite doze ponosa isticalo se da je „dobra agitacija osnovni preduvjet za mobilizaciju studenata za radne akcije“. 48

Nije se radilo samo o ljetnim radnim akcijama izvan Zagreba već i o onima koje su se održavale tijekom akademske godine, a bile su usmjerene na izgradnju popratne infrastrukture za studente u samom Zagrebu, ponajprije na izgradnju „Studentskog naselja na Laščini “i kasnije na Sveučilišnom gradu u Dubravi. ${ }^{49}$

Učinak tih radnih akcija prezentirao se kao velik uspjeh: „... na Laščini u toku nepunih godinu dana 7 stambenih objekata a također su završeni radovi na izgradnji velikog društvenog objekta. Tokom slijedeće školske godine naselje na Laščini biti će potpuno dovršeno

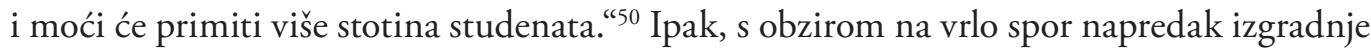
studentskih domova i menzi (o čemu će još kasnije biti riječi), stvarnost je očito bila barem donekle različita od ovih pohvala.

\section{6. STUDENTSKI LIST}

Jedan od instrumenata koji se koristio u provođenju „agitacije i propagande“ bio je i tisak, a kada su u pitanju zagrebački studenti, radilo se i o posebnom omladinskom listu namijenjenom upravo njima - Studentskom listu. On se eksplicitno spominje i kada je riječ o popularizaciji radnih akcija, pored, naravno, članaka o radnim akcijama koji su se sva-

\footnotetext{
45 HR-DAZG-684, Referati Sveučilišnog komiteta, O radnim akcijama, 1948.

46 Isto.

47 HR-DAZG-684, Referati Sveučilišnog komiteta, 1948.

48 HR-DAZG-684, Referati Sveučilišnog komiteta, O radnim akcijama, 1948.

49 HR-DAZG-684, Referati Sveučilišnog komiteta, Politička situacija na sveučilištu, 1949.

50 Isto.

51 Isto.
} 
kodnevno objavljivali u tisku. Smatralo se da bi Studentski list trebao otvoriti „rubriku u svrhu popularizacije radnih akcija". 51

Studentski list je godinama funkcionirao kao vrsta propagandnog biltena koji se koristio za prenošenje poželjnih ideoloških poruka i provođenje akcija u skladu s partijskom politikom. Na njegov rad osvrtalo se i u referatima sastavljanima u sklopu Sveučilišnog komiteta pa se tako 1949. pisalo:

Na kraju ćemo se osvrnuti na „Studentski list“ - organ NOH Zagrebačkog Sveučilišta. "Studentski list“ je kroz proteklu školsku godinu izlazio redovno jedan put tjedno, sem u februaru, u vrijeme semestralnog ferija. Glavni nedostatak i poteškoća s kojim se je „Studentski list" borio bio je pomanjkanje kadra u redakciji, koji je bio riješen tek u II. semestru. To je imalo uticaja na sadržaj i kvalitet lista. Drugi nedostatak je bio pomanjkanje planova za duži period. I taj problem se riješio tek u II. semestru, što je uticalo da se je kvalitet lista znatno popravio. ${ }^{52}$

Studentski list imao je niz rubrika: političku, stručnu, fiskulturnu, teoretsko-ideološku, kulturnu i rubriku radnih akcija. U partijskom komitetu smatralo se kako je u početku „najviše nedostataka imala politička i kulturna rubrika, dok su ostale zadovoljavale“. Tim se rubrikama zamjeralo da njihov materijal „nije bio uvijek aktualan i bio je često apolitičan“, što je - naravno - u to vrijeme predstavljalo snažnu kritiku. Političkoj rubrici prigovaralo se da je njezin oblik i sadržaj „neodređen“. Smatralo se ipak da „donošenjem planova za duži period postiglo se je da se kvalitet rubrika popravio i da on po mišljenju ureda za Informacije vlade NRH je u zadnje vrijeme jedino i zadovoljavao". 53

\section{STUdentski ŽIVOT}

\section{I. SOCIJALnO PODRijETlo STUdenata}

U skladu s vladajućom ideologijom, povećanje broja studenata radničkog i seljačkog podrijetla i službeno se isticalo kao cilj vlasti i Partije. Na sveučilišnoj partijskoj konferenciji isticalo se važnost tog pitanja „imamo li u vidu profil intelektualca-stručnjaka, koji treba našoj zemlji, a i socijalni sastav našeg Sveučilišta“. ${ }^{44}$ Ipak, situacija se nije mijenjala očekivanom brzinom. I dvije godine nakon rata velik je broj studenata i dalje potjecao iz "građanskih krugova“, iako se odnos u tom vremenu „nešto izmijenio“ u korist onih radničkog i seljačkog podrijetla. ${ }^{55}$ Detaljnih podataka za razdoblje neposredno nakon rata nemamo, no u Izvještaju s V. sveučilišne partijske konferencije 1949. godine nalazimo sljedeće podatke: $12 \%$ radničkog podrijetla, $18 \%$ sa sela, $55 \%$ djece namještenika, $7 \%$ djece trgovaca

52 HR-DAZG-684, Referati Sveučilišnog komiteta, Politička situacija na sveučilištu, 1949.

53 Isto.

54 HR-DAZG-684, Referati Sveučilišnog komiteta, Izvještaj Sveučilišnog komiteta KPH o radu partijske organizacije na Sveučilištu u razdoblju od oslobođenja zemlje do danas, 1949.

55 HR-DAZG-684, Referati Sveučilišnog komiteta, o međunarodnoj političkoj situaciji, našoj unutarnjoj politici i zadacima Partije na sveučilištu, 1949. 
i zanatlija, $8 \%$ ostalih. Iz tih podataka Partija izvlači za sebe uznemirujući zaključak da je među studentima „relativno malen broj onih kojim je već po njihovom socijalnom porijeklu linija naše Partije bliža i lakše razumljiva". 56

U dokumentu iz godine 1954. nalazimo podatke za prethodnu akademsku godinu koji se ne razlikuju bitno od ranije navedenih, odnosno manje promjene koje možemo primijetiti idu u pravcu suprotnom od priželjkivanog. Socijalni sastav 1952./1953. godine izgledao je kako slijedi: „10\% radnička djeca, 58\% namještenika, 14\% seljaka, 8\% zanatlija, 10\% ostalih. ${ }^{\text {s57 }}$

Promjena socijalnog sastava studentske populacije smatrala se potrebnom s obzirom na utjecaj podrijetla studenata na konačan lik intelektualaca i stručnjaka, koji su na kraju studija trebali napustiti sveučilišne klupe i biti nositeljima razvoja zemlje u skladu s vladajućom ideologijom. Pisalo se: „Sasvim je jasno da studenti sa sobom donose pozitivne i negativne strane svoje okoline u kojoj žive navike svog ranijeg i sadašnjeg odgoja, kao i previranja, koja nastaju pod utjecajem našeg razvitka u krugovima iz kojih su potekli." ${ }^{\text {"58 }}$ Polovinom pedesetih godina smatralo se ipak da je moguće utjecati na oblikovanje novih generacija stručnjaka intenzivnim i pravilnim radom, za što su bili zaduženi upravo komunisti na Sveučilištu. ${ }^{59}$

\section{2. Kultura I SPORT}

U svome radu partijska organizacija na Sveučilištu posvećivala je svoju pozornost svim sferama javnog života pa je sustavno razmatrala i kulturnu i umjetničku djelatnost te zabavni život studenata. U kasnijim izvještajima ovako se to opisivalo:

Kulturno-umjetnički rad na našem Sveučilištu otpočeo je 1945/46 godine najprije preko najprimitivnijih formi: usmenih i zidnih novina. Kasnije osnovane Kulturno-prosvjetne sekcije radile su na omasovljenju toga rada. 1946/47 godine je surađivalo na Kulturno-prosvjetno polju do 2.000 studenata. Karakteristična crta za taj period je velika masovnost, mnogo priredaba a slaba kvaliteta. Prekretnicu u tom periodu je baš učinio I. Majski festival, kojega je Narodna omladina organizirala kao izraz radosti nad Petogodišnjim planom i zbog učešća na izgradnji pruge Šamac-Sarajevo. Na II. Majskom festivalu 1948 godine smo zabeležiti u svim granama kulturno-umjetničkog rada uspon u kvalitetnom pogledu. Pristupili smo ka višim formama organizacije - formiranju kulturno umjetničkog društva. Naše KUD „Ivan Goran-Kovačićc“ osnovano je 23.X.1948 godine od samostalnih centralnih grupa, koje su već postojale na Sveučilištu i to: pjevački zbor, folklor, studentsko kazalište literarna sekcija. ${ }^{60}$

Početnu stihiju u kulturnom radu partijske strukture nastojale su obuzdati. Ipak, kasnije je procijenjeno da to nije bilo dobro. Već 1948. godine ocjenjivalo se da „pojednostavljenje

\footnotetext{
56 HR-DAZG-684, Referati Sveučilišnog komiteta, Izvještaj Sveučilišnog komiteta KPH o radu partijske organizacije na Sveučilištu u razdoblju od oslobođenja zemlje do danas, 1949.

57 HR-DAZG-685, Sveučilišni komitet, kut. 27, Referat na Izvanrednoj konferenciji Sveučilišnog komiteta SK u 1954 godini.

58 Isto.

59 Isto.

60 HR-DAZG-684, Referati Sveučilišnog komiteta, Politička situacija na sveučilištu, 1949.
} 
kulturno-prosvjetnog rada i centralizacija koja je sprovedena ukidanjem folklornih i glumačkih skupina pa i horova po fakultetima sve je to u izvjesnoj mjeri doprinijelo negdje i potpunom opadanju kulturno-prosvjetne aktivnosti u okviru fakultetskih organizacija." ${ }^{61}$ $\mathrm{Na}$ temelju ovog zaključka najavljena je promjena te politike.

Osim nastupa na kulturnim manifestacijama, Kulturno-umjetničko društvo bavilo se i organizacijom zabava među studentima. Godine 1948. Sveučilišni komitet KP-a bio je dosta zadovoljan tom stranom djelatnosti KUD-a: „Vesele večeri su organizirale fakultetske organizacije mnogo bolje nego prošlih godina. Pojave opijanja su bile rijetke. (...) Zabavni programi imali su politički akcenat i bili ispunjeni sa događajima iz brigada i školske godine. Na nekim fakultetima su organizirali zabave apsolventi. "“2

Sportske aktivnosti, odnosno „fiskulturni rad“ bio je također važan dio studentskog života iz perspektive Komunističke partije, a bio je povezan is kulturnim radom, ali i brigom za zdravstvenu, odnosno fizičku kondiciju studenata. U skladu s generalnom politikom KPJ u vezi s time, ${ }^{63}$ u prvim godinama nakon rata prednost se davala „fiskulturi“, koja se shvaćala kao masovno uključivanje što širih krugova u te aktivnosti. Tome je služila, primjerice, tzv. „Fiskulturna značka“, odnosno odlikovanje fiskulturnika. Partijske vlasti nisu bile dokraja zadovoljne postignutim rezultatima jer komunisti i članovi SKOJ-a često nisu pokazivali iskren interes za time, već su se akcije provodile „više radi toga, jer je to bila part. direktiva“. „Naše partijsko i SKOJevsko članstvo“, ocjenjivalo se, „nije shvatilo i vidjelo da među studentima postoje uvjeti za masovno razvijanje fiskulture, nije shvatilo da fiskultura na sveučilištu pretstavlja jednu od vrlo dobrih formi za vezivanje studenata za našu organizaciju. " ${ }^{64}$ Sport na Sveučilištu razvijao se u okviru Sportskog društva „Mladost“ koje je okupljalo „najbolje sportiste Sveučilišta“.65

\section{3. Materijalni uvjeti Života studenata}

Partija je pomno pratila i materijalne uvjete života studenata, što postaje važan dio izvještaja nakon 1948. godine. Te godine u izvještaju na Sveučilišnoj konferenciji KP-a moralo se konstatirati: „Stambeno pitanje studenata također je u 1948 godini bilo dosta teško. U domovima je smješteno svega 1.100 studenata, dok su potrebe bile daleko veće. ${ }^{\text {"66 }}$ Optimistično se isticalo kako će se stanje uskoro značajno popraviti izgradnjom novih studentskih domova. ${ }^{67}$ Ipak, i 1949. ustanovljeno je da su materijalni uvjeti studenata nezadovoljavajući i u pogledu smještaja studenata i kapaciteta menzi. U tom su času u Zagrebu postojala samo dva studentska doma

61 HR-DAZG-684, Referati Sveučilišnog komiteta, O radu kroz prošli semestar i zadacima u ljetnom semestru, (1947/1948).

62 HR-DAZG-684, Referati Sveučilišnog komiteta, Politička situacija na sveučilištu, 1949.

63 Hrvoje Klasić, „Fiskultura u službi naroda. Uloga tjelesnog odgoja u stvaranju jugoslavenskog socijalističkog društva 1945.-1952.“, u: Stvaranje socijalističkog čovjeka, 201-220.

64 HR-DAZG-684, Referati Sveučilišnog komiteta, 1948.

65 HR-DAZG-684, Referati Sveučilišnog komiteta, Politička situacija na sveučilištu, 1949.

66 HR-DAZG-684, Referati Sveučilišnog komiteta, Izvještaj o situaciji i radu partijske organizacije na Sveučilištu za 1948. godinu.

67 Isto. 
sa smještajnim kapacitetom od samo 1.000 studenata „pod prilično lošim uslovima“. „Sobe u kojima spavaju studenti su prenatrpane“, pisalo se, „(u jednoj sobi spava 8-12 studenata) a namještaj je nepovoljan. Studenti se koriste domovima uglavnom za spavanje dok ih za učenje ne mogu koristiti u dovoljnoj mjeri.“68 Iz godine u godinu (s obzirom na povećanje broja studenata) problem je postajao sve veći. Anketa koju su proveli u Komitetu za naučne ustanove i visoke škole među maturantima srednjih škola pokazivala je da su naredne godine na studij planirala doći 774 nova studenta koji „reflektiraju na stanovanje u Studentskom domu“. 69

Usprkos tomu što se tema studentskog smještaja opetovano ponavlja u raspravama i izvještajima, situacija se vrlo sporo poboljšavala. Ni 1953. godine kasnije nije bilo razloga za zadovoljstvo:

Uzmimo na primjer stambeni problem studenata. Bilo je investicija, koje bi bile - po našem mišljenju - mnogo korisnije upotrebljene, da se, na primjer, izgradio jedan ili dva studentska doma. Neki će naši drugovi, nadamo se, to u diskusiji argumentirati. Zato je potpuno pravilan zahtjev studenata, da se što prije pristupi izgradnji studentskih domova. $S$ time u vezi komunisti se moraju založiti, da se jedanput raščisti da li su članovi sveučilišnog kolektiva (nastavnici i studenti) građani, o kojima treba da se brinu samo republički organi, ili i gradski, naročito kada se radi o praktičnom rješavanju spomenutog pitanja. ${ }^{70}$

Također, pitanje prehrane studenata nije davalo temelja za zadovoljstvo i godinama nije riješeno. Godine 1948. kapacitet postojećih studentskih menzi iznosio je, prema izvještajima, 3.000, a u njima se hranilo oko 5.500 studenata. Pored nedostatka mjesta u menzama, problem je predstavljao nedostatak stručnog osoblja. Opskrba osnovnim artiklima, prema podacima Sveučilišnog komiteta KP-a, poboljšala se, međutim, često je nedostajalo masnoća, a naročito mesa, „uslijed čega je hrana jednolična i kvalitativno loša““71 Te se godine moralo konstatirati i to da je dio problema proizlazio iz nedovoljne organiziranosti sustava. Komitet za naučne ustanove i visoke škole nije još preuzeo Socijalni ured studenata. Njime su uglavnom rukovodili studenti volonteri, zbog čega je došlo do „niza subjektivnih nedostataka u radu".72

Kapacitet menzi nije se dovoljno brzo povećavao. Za godinu 1949. nalazimo dva dokumenta koji donekle različito opisuju stanje, iako podaci ne odstupaju značajno, a razlike mogu proizlaziti iz toga da su ti dokumenti nastali tijekom iste godine, ali s određenim vremenskim razmakom. Dakle, prema jednom od njih, godine 1949. u Zagrebu je djelovalo 7 menzi s 5.000 do 5.100 korisnika, a predviđalo se da će se naredne godine njihov broj povećati za 1.674 nova studenta. ${ }^{73}$ Ipak, moralo se priznati i da je „hrana po menzama bila loša“ ${ }^{74}$ Prema drugom dokumentu iz iste godine, postojalo je 6 studentskih menzi $s$

\footnotetext{
68 HR-DAZG-684, Referati Sveučilišnog komiteta, Politička situacija na sveučilištu, 1949.

69 Isto.

70 HR-DAZG-684, Referati Sveučilišnog komiteta, Referat sa VII. Konferencije SK Sveučilišnog Komiteta u 1953 godini.

71 HR-DAZG-684, Referati Sveučilišnog komiteta, Izvještaj o situaciji i radu partijske organizacije na Sveučilištu za 1948. godinu.

72 Isto.

73 HR-DAZG-684, Referati Sveučilišnog komiteta, Politička situacija na sveučilišsu, 1949.

74 Isto
} 
5.300 korisnika. Očekivalo se da će se ovaj broj uskoro popeti na 6.000 jer je bilo studenata „koji još uvijek nisu došli, ili će prijeći iz raznih radničko-namješteničkih menza u gradu Zagrebu“.75 Govorilo se o tome da „općenito uzevši stanje u menzama ne zadovoljava“, i to iz sljedećih razloga: kapacitet menzi bio je nedovoljan, a obroci su se morali dijeliti u više smjena; kuhinje su bile zastarjele; nedostajalo je posuđa, zbog čega se radilo sporo, a i higijena je bila upitna; problem je predstavljala opskrba nekim namirnicama, ponajviše mesom i masnoćama. ${ }^{76}$

Materijalni uvjeti života studenata utjecali su i na njihovo zdravstveno stanje, koje je bilo zabrinjavajuće. „Slaba ishrana izvan svake sumnje utječe i na zdravstveno stanje studenata“, pisalo se 1949. godine: „Točnih statističkih podataka nemamo, ali prema izvještaju Sveučilišne poliklinike procenat aktivne tuberkuloze se penje. Prema rezultatima posljednjeg fluorografskog snimanja/ 7.163 pregleda/ utvrđeno je 6,5\% inakt. tuberkuloze, a 3,3\% aktivne tuberkuloze." ${ }^{\text {"77 }}$

Uobičajeno se u partijskim izvještajima govorilo o uspjesima. Primjerice, 1949. navodilo se: „Tokom ove školske godine su prema ranijim godinama postignuti uspjesi u pogledu izhrane studenata" ${ }^{78}$ Ipak, promatrajući sliku koju opisuju materijali Sveučilišnog komiteta KP-a i rezultate politike koja se provodila u vezi s osiguranjem studentskog standarda, može se zaključiti kako je, bez obzira na važnost tog pitanja, državna politika u tom pogledu bila slabo učinkovita, a svakodnevni život zagrebačkih studenata u 1940-ima i 1950-ima opterećen je mnogim prizemnim problemima.

\section{ZAKLJUČAK}

Zagreb je u desetljećima nakon rata u NR Hrvatskoj bio jedini sveučilišni centar (osnivanje 1954. Filozofskog fakulteta u Zadru malo je toga promijenilo) i jedan od triju sveučilišnih centara s tradicijama u cijeloj Jugoslaviji. U planovima preobražaja (modernizacije) zemlje koje su si postavljali komunisti, novi naraštaji visokoobrazovanih mladih ljudi igrali su značajnu ulogu. Ti su mladi stručnjaci trebali imati znanja potrebna za razvoj privrede i društva, a istovremeno predstavljati čvrst temelj vladavine Komunističke partije.

Partija je, uspostavljajući svoju vlast, ulazila u sve sfere društva, pa tako i u akademsku zajednicu uz pomoć partijskih organizacija (te SKOJ-a i NSO-a), kako bi je usmjeravala i kontrolirala. Nastojala je također prikupiti sve potrebne informacije o sveučilišnoj zajednici, kako o studentima tako i o nastavnicima. Stoga dokumenti Sveučilišnog komiteta KPH predstavljaju vrlo zanimljivu građu koja govori mnogo o situaciji na Sveučilištu u Zagrebu i među njegovim studentima.

\footnotetext{
75 HR-DAZG-684, Gradski komitet SKH, kut. 27, fasc. II/7: Komitet Sveučilišta (Pogrešno datiran na 1952. godinu, a potječe najvjerojatnije iz 1949.).

78 HR-DAZG-684, Referati Sveučilišnog komiteta, Politička situacija na sveučilištu, 1949.
} 
Pozornost se primarno, pogotovo u početku, posvećivala političkoj situaciji (uključujući oblike indoktrinacije, od predavanja i sastanaka do odlazaka na radne akcije), pa i didaktičkim uspjesima, ali i ostalim područjima studentskog života, poput kulturnih i sportskih aktivnosti studenata (koje su u principu bile u službi prvog, odnosno bile su sastavni dio nastojanja da se oblikuje „novi socijalistički čovjek“). Napokon, analizirala se i ekonomska te zdravstvena situacija studenata (primarno smještaj i prehrana). U kasnijem razdoblju na najvišim partijskim forumima nije se posvećivalo previše pozornosti političkom stanju na Sveučilištu. Kada je to postalo predmetom rasprave na sjednici Izvršnog komiteta CK SKH 1955. godine na temelju pisanog izvještaja, uglavnom se radilo o analizi kretanja broja studenata, nastavnika i diplomiranih, o pitanjima izgradnje sveučilišnih zgrada i studentskih domova i slično. ${ }^{79}$

Za poznavanje situacije na Sveučilištu, ali i za istraživanja svih aspekata studentskog života, od političkog stanja do svakodnevnog života, građa pohranjena u fondu Sveučilišnog komiteta SKH predstavlja iznimno zanimljivo vrelo.

\section{$\cos$ \\ The students of Zagreb in THE FiRst DeCADE AFTER WORLD WAR II}

Summary: The immediate wake of World War II is a time of extensive social changes, which are particularly evident in Zagreb. As the only Croatian university town at the time, Zagreb has rightfully attracted the attention of researchers focusing either on the history of science, or on university life in its various aspects, from the political to the quotidian.

The university saw a surge in the number of students after 1945, which, along with the political changes occurring at the time, transformed not only the social structure of the student population, but also the teaching methods, the relationships between the professors and the students, and many other things, such as life at the university and the students' everyday problems. The new authorities strove to control various aspects of the students' lives through different party-oriented youth organizations, documenting these efforts in a wealth of archival materials, which are still waiting to be explored.

This paper uses the archival records of the University Committee of KPH/SKH (the Communist Party of Croatia/the League of Communists of Croatia) in Zagreb to analyze the political opinions of the University's student population, as well as the numerous facets of student life described in various party reports. The communists' political opponents and the fluctuation of the KPH/SKH membership at the University are examined to provide insight into the overall political situation at the University. Different forms of political propaganda and actions utilized by the Party to establish stricter control over the student population (such as youth labor actions) are also analyzed, with particular focus on the participation in youth organizations. The data on the social structure of the student body presented in the archival records is also cited, as well as the information concerning the various facets of the students' day-to-day lives in the first post-war decade. An over-

79 B. Vojnović (prir.), Zapisnici Izvršnog komiteta Centralnog komiteta Saveza komunista Hrvatske, sv. IV.: 1955. - 1959., Zagreb 2010., 92-136. 
view is provided of the cultural and sporting events that the students participated in, as well as the conditions they lived in.

Key words: University of Zagreb, Communist Party of Croatia/League of Communists of Croatia, students, the University Committee

\section{$\cos$}

\section{Izvori}

Državni arhiv u Zagrebu (HR-DAZG)

HR-DAZG-684, fond Gradski komitet Saveza komunista Hrvatske (SKH).

HR-DAZG-685, fond Sveučilišni komitet Saveza komunista Hrvatske (SKH).

Hrvatski državni arhiv (HR-HDA)

HR-HDA-1220, fond Centralni komitet Saveza komunista Hrvatske (CK SKH), serija Agitprop.

\section{Literatura}

Hrvoje KLasić, „Fiskultura u službi naroda. Uloga tjelesnog odgoja u stvaranju jugoslavenskog socijalističkog društva 1945.-1952.“, u: Stvaranje socijalističkog čovjeka. Hrvatsko društvo i ideologija jugoslavenskog socijalizma (ur. Igor Duda), Zagreb - Pula 2017., 201-220.

Stjepan Matкović, „Ocjene Uprave za agitaciju i propagandu KP Hrvatske o povjesničarima na Sveučilišstu u Zagrebu do početka 1950-ih", u: Kultura sjećanja: 1945. Povijesni lomovi i svladavanje prošlosti (ur. Sulejman Bosto i Tihomir Cipek), Zagreb 2009., 221-238.

Andrea MatošEvić, „Posrednici u stvaranju socijalističkih ljudi na omladinskim radnim akcijama: utopija, dijalektika i vrijeme“, u: Stvaranje socijalističkog čovjeka. Hrvatsko društvo i ideologija jugoslavenskog socijalizma (ur. Igor Duda), Zagreb - Pula 2017., 75-96.

Magdalena Najbar-Agičrć, Kultura znanosti ideologija. Prilozi istraživanju politike komunističkih vlasti u Hrvatskoj od 1945. do 1960. na polju kulture i znanosti, Zagreb 2013.

Reana SenjKović, Svaki dan pobjeda. Kultura omladinskih radnih akcija, Zagreb 2016.

Tatjana ŠArIć, U vrtlogu komunizma. Mladi Hrvatske 1945.-1954., Zagreb 2017.

Branislava Vojnović (prir.), Zapisnici Izvršnog komiteta Centralnog komiteta Saveza komunista Hrvatske, sv. IV.: 1955. - 1959., Zagreb 2010.

Branislava Vojnović (prir.), Zapisnici Politbiroa Centralnog komiteta Komunističke partije Hrvatske 1945. - 1952., sv. II.: 1949. - 1952., Zagreb 2006. 
